\title{
Questions of Identity: The Structure of the Cohen Family in Puigcerdá in the Early Fourteenth Century
}

David J. WASSERSTEIN

Tel Aviv University

On 21 November 1306, in the small Pyrenean city of Puigcerdá, a Jewish woman called Gentil, married to Jacob b. Abraham Cohen, sick and on her deathbed, made her will. In it, she left legacies to her children and grandchildren. The circumstance that she made her will in Latin led to its survival, and it has recently been published ${ }^{1}$. Almost exactly fifteen years later, to the day, on 20 November 1321, a Jewish man called Jacob ben Abraham Cohen, also ill and close to death, made his will, leaving his property to his children and grandchildren. The same circumstance, that he made his will in Latin, led to its survival, and like the first one, it has recently also been published 2 .

From these two documents we can reconstruct the shapes of the immediate families of these two testators. The results look something like this 3 :

1 R. I. Burns, Jews in the Notarial Culture, Latinate Wills in Mediterranean Spain, 1250-1350 (Berkeley - Los Angeles - London 1996) pp. 180-182, doc. 38. The husband of this Gentil is not unknown: he seems to be the same Jacob ben Abraham Cohen who acted as witness for the will of a certain Regina, also in Puigcerdá, on 23 October 1306, just a month before his own wife made her will, possibly during her final illness (BURNS Latinate Wills p. 101, and pp. $177-178$ doc. 35 ). If he is not the same man, then we are compelled to conclude that this town, which had no more than some fifty or so adult male Jews around this time (see below), had two people called by this same name.

2 BURNS Latinate Wills pp. 186-187 doc. 42. Interestingly, in giving the archival locations of these two documents, Burns reports that each of them is found on folio 17 of its respective volume.

3 I take these trees, with slight modifications, essentially of layout, from BURNS Latinate Wills pp. 109 and 98 respectively. 
1. Family of Gentil, wife of Jacob ben Abraham Cohen

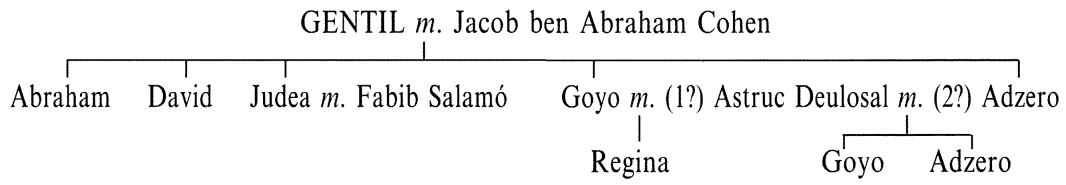

2. Family of Jacob ben Abraham Cohen, husband of Covallis

JACOB ben Abraham Cohen m. Covallis

As can be seen, the degree of overlap, or similarity, between these two family-reconstructions is very great. In his description of the family of Jacob, Burns says that the «family members here correspond in part to those of 1306 in Gentil's will ... Is the wife here that Gentil, and Philippus [i.e. Felip] Fabib?»4. And in that of the family of Gentil, he says that it «relates to that of Jacob [ben] Abraham Cohen» s. He is clearly quite right to point to the similarity. There are very many points at which these two trees converge:

a) Each contains a husband called Jacob ben Abraham Cohen.

b) The wife in the two cases has, it is true, apparently different names, but the situation is not so clear-cut as all that. Although we do not have reproductions of these documents in Burns' valuable book, he does provide descriptions of some of the problematic aspects of the texts which he transcribes and publishes here. In his description of the will of Jacob ben Abraham, he tells us (p. 97) that the wife, by then (1321) dead, was called «Covallis - Convallis?»; and (p. 227 n. 20) that «The wife's name may begin with $G$ and have abbreviatory over-

4 Burns Latinate Wills p. 98.

5 BURns Latinate Wills p. 109. 
stroke» 6 . And he adds, or repeats (p. 98), that «The wife "Covallis" (genitive) has an abbreviatory overstroke promising extra letter(s), and her name remains something of a mystery». In his description of the will of the wife, he tells us (p. 109) that "Gentil in the manuscript follows the now-antiquated Gentill spelling of the Catalan name for 'cherished', 'gracious', 'highborn' (and even 'gentile'!)». From these accounts of the two name-forms it is clear that what Burns has very conscientiously and cautiously read as a genitive Covallis could equally be read as a genitive form of Gentill.

c) Each of the husband-and-wife pairs has a son called Abraham.

d) Each of the husband-and-wife pairs has a further son called David (though the spelling, as also the linguistic identity, of the name varies in the two documents; but this is scarcely of any significance in documents of this sort).

e) Each of the husband-and-wife pairs has a daughter called Judea.

f) That daughter has in both cases a husband; although the names differ, the forms of that husband's name can be to a large degree reconciled. In the earlier document, of 1306, Burns gives it as Fabib Salamó, and he says of it (p. 109) that «Fabib may be Arabic Habīb or else Hebrew Habib ('beloved')». However, what the document itself actually has is Fabib, followed by the word Maymo, deleted, and with the name Salomonis inserted above the line: «Item dimitto Iudee filie mee uxori Fabib [deleted: Maymo] \Salomonis/ de Barchinona» 7. This is of significance, because in the document of 1321 we find that the husband of the daughter Judea is named as Philippo Maimo. If the equivalence between Philippo and Fabib (what-

6 At Latinate Wills p. 227 n. 21, BURNS says further that «The Covallis surname may relate to Cavaller?». I find this a little odd: if it is the wife's name, surely it should be seen as a first name, not a surname. If it is a surname, what sort of surname is it, in terms of family structure rather than linguistically? and what is her first name? and why is she not called by her first name or by her first name in some form of linkage with this, as a surname, here?

7 Burns Latinate Wills p. 181 doc. 38. The symbols \and / indicate an insertion above the line. 
ever the meaning to be attached to Fabib may be) is not immediately obvious, the occurrence in both documents of the nameform Maymo / Maimo must arouse our interest. It suggests that as early as 1306, the man in question had the name Maymo / Maimo in some form as part of his identification. The document of that year taken on its own, and containing a deleted Maymo, replaced with Salomonis, might suggest simply that a scribal error had occurred, and been corrected. However, the occurrence of the name Maimo in the document of 1321 as well suggests rather that the name Maimo was part of the man's identification, both in 1306 and in 1321. Its replacement by the name Salomonis (= '[son] of Solomon') in the document of 1306 suggests simply that it was replaced there because it was not the name of his father and a father's name was considered more suitable for that context. The difference between Fabib and Philippo is odder. Fabib may indeed, as Burns suggests, represent the Hebrew Habib (given the apparent Barcelonan background of the man, an Arabic connection seems less likely, since Barcelona had not been ruled by Muslims since 801 , and Arabic culture was always a stranger there. But the Hebrew and the Arabic forms are of course etymologically and semantically identical). It may well be that Philippus was used as a secular equivalent of Fabib because of the common initial sound, a feature which is far from unknown in Jewish onomastic practice, as Burns himself notes. But while this remains a difficulty, it cannot be regarded as very serious, particularly given the additional possibility here of some minor scribal confusion.

g) Each of the husband-and-wife pairs has a deceased daughter.

h) Each of the husband-and-wife pairs has, not through the two sons or the daughter called Judea, three granddaughters; two of these granddaughters have names which are identical in the two wills: Regina and Goyo / Guoyo ${ }^{8}$. All of these three

8 BURNS Latinate Wills p. 98: "The daughter's name Guoyo or possibly Goyo has a preceding false start deleted. If Guoyo, it is a variant of the feminine name Goyo [seen in a previous document]; if Guoyx, it is a version of the better-known Goig. Both versions of Catalan Goig mean 'joy'». And (pág. 109): "The name Goyo seems a variant either of Goig or of Provençal Goiona». The meaning of the first part of what Burns says here is not transparent. 
granddaughters are descended from these grandparents in the female line.

These points of identity between the two family reconstructions are very strong indeed. Taken individually, they are no more than striking, but taken in combination they are extremely strong. They are so strong that one feels compelled to assert the identity of the two family reconstructions, as representing a single family. However, there are also differences, and these can be regarded as making the picture more problematic:

i) The name-forms of the wife differ between the two documents, as has been seen. Although we can persuade ourselves, if we wish, that they can be reconciled, the fact remains that, at least at first glance, they are different, and need to be reconciled.

ii) The names of the son(s)-in-law differ. As has been seen, in one document the son-in-law is called Fabib and in the other Philippus; and while Maymo does occur in the earlier document, and seems to be reflected in the Maimo of the second, the fact remains that it was deleted in the first document and replaced there by Salomonis.

iii) The number of deceased daughters differs; as has been seen, in 1306, there were two deceased daughters, but by 1321 these have become only one.

iv) The names of these deceased daughters differ: in the earlier there are two deceased daughters, called Goyo and Adzero, while in the later document there is only one, and she is named there as Suora.

v) The names of the granddaughters differ too: in 1306 the deceased Goyo was the mother of a single daughter, called Regina; and her deceased sister Adzero was the mother of two daughters, named Goyo and Adzero. In 1321, by contrast, we hear of three granddaughters, called Sança, Regina and Guoyo, all apparently of the same mother.

These are troubling differences; they are troubling both because we cannot easily reconcile all of them with the suggestion that we have indeed a single family here; and they are the more troubling because it seems clear that we cannot have two families here. Puigcerdá at this time had a very small overall 
population: in 1359 , there were no more than 660 Christian households 9 . For an earlier period, Burns estimates that there were «at least fifty male adult Jews» living at Puigcerdá; living mixed among the Christians, they were growing in number, and constituted some 10 percent of the total population around the end of the thirteenth century ${ }^{10}$. This means that there were too few Jews in Puigcerdá at this time for there to have been two families there with so many shared characteristics; and the number, the type and the range and comprehensiveness of the positive features of the comparison between the two reconstructions are so great that we must accept that the identification is correct. How then can we deal with those differences that remain impervious to easy explanation?

It seems to me that the real difficulties here are those numbered iii, iv and $\mathrm{v}$ above. The first two, touching the names of the wife and of the son-in-law, can, as has been seen, without too much difficulty be dealt with. But the others look much harder. I think, though, that an explanation is possible. We should note, first, that in each case we are dealing with three granddaughters, all of whom were alive both in 1306 and 1321 . Secondly, as to their mother(s), daughter(s) of the two testators, there may have been one or two, but in either case, we are dealing with a person or persons who is/are already dead as early as 1306. It is also to be noted that two out of the three names of the granddaughters are identical in the two cases: Regina and Guoyo / Goyo. The problems really begin with the names of the deceased daughter(s), Goyo and Adzero in the document of 1306 and Suora in that of 1321; and with the names of the third granddaughter(s): Adzero (in 1306) and Sança (in 1321).

As to the former problem, the name(s) of the daughter(s) of the testators, it is worth noting that we have two names in the earlier document, of 1306, and only one in the later document, that of 1321. Two explanations suggest themselves: one is that the fact of there having been two daughters had in the fifteen

9 BuRns Latinate Wills p. 109. As he points out, this was after the ravages of the Black Death, and should be adjusted accordingly for that context for the half century before that.

10 BURns Latinate Wills p. 96. 
years since the death of their mother in 1306 been somehow forgotten by 1321 (they themselves had both died before 1306); and they had somehow been assimilated into a single personality, as the mother of the granddaughters. From one point of view, it was by 1321 of little significance whether they had been one or two in number. What was of significance was that the mother of each of the granddaughters was a daughter of the testator in each case.

A second possibility lies in the curious name given to the single deceased daughter referred to in the later document: she is not called there by either of the two names which the earlier document provides for the two daughters of Gentil, Goyo and Adzero. We might have expected one of these to have survived. Instead, she is called Suora. Burns identifies this as «probably Catalan Sor, for sister» (p. 97): the text says: «In primis dimitto Sancie neptis [= nepti] mee, filie suore filie mee quondam ...». We may easily envisage the dying man dictating to the scribe or notary who was writing down his instructions 11 ; the notary will have known little, if anything, of the details of members of the family who were long dead. The testator will have given an instruction with some reference to a deceased daughter of his, and then followed it with another in which he mentioned the daughter of a sister of that deceased daughter: we can easily suppose that the "sister» will have been turned into a name, and the whole expression somehow shortened. In this way, we can understand the disappearance of one of the deceased daughters, a disappearance which has no obvious legal significance, since the daughters in question were both long dead anyway, and since their three daughters all still fig-ure in the disposition of their grandfather's estate individually and by name.

There is an additional point which might have eased the path to such a situation. This is the fact that the two sisters had not only both been married, they had both been married to the same man, Astruc Deulosal. They had both produced daughters with him, daughters whom he will have brought up,

11 For details of testamentary regulations and practice, as this latter can be deduced from our materials, see BURNS Latinate Wills especially pp. 45-46, with pp. 210-211 nn. 33-42. 
presumably alone, since at least 1306 (by when both of his wives were already dead). The result by 1321, when these daughters were themselves already adults, is quite likely to have been some degree of obscurity or indifference as to the specific individual identities of their mothers, indifference strengthened by the absence of any legal significance to the fact of there having been two of them.

There remains the problem of the names of these granddaughters. As has been seen, two of the names match in the two documents: Regina-Regina and Goyo-Guoyo. The only significant difference lies in the equivalence of Sança-Adzero. Here, on the assumption that the equivalence of the first two pairs of names is indeed correct, we need do no more than assume that one of these two names, Adzero and Sança, represents a familiar name or endearment. Since from the earlier document we know that the name of the second deceased daughter of Gentil was Adzero, we may assume that her daughter Adzero also had that as her formal name. Sança would then be some sort of diminutive.

We need do no more than assume this -but equally we do need to assume this. May we? More broadly, can an explanation of this kind for the problem represented by these two documents be acceptable, methodologically and otherwise? I think that this, or something like it, should be seen as acceptable, for a very simple reason: given the facts mentioned above, the size of the Jewish community in Puigcerdá at this time, in combination with the nature and number of the positive features of the overlap, we must accept it. If we do not, then logic compels only one other explanation, and that is that we have here two distinct families. But if that is the case, then we are faced with a situation in which we have two families, active at a distance of fifteen years from each other, in a single small town, with only some fifty Jewish families in it, two families which shared, as we have seen, a very great number of similarities. The degree of coincidence is so remarkable as to make this situation wholly unacceptable. With all the slightly Procrustean implications discussed here, we have to see these two reconstructions as representations of a single family. 


\section{A note on the marriages of Astruc Deulosal}

It is of interest to note that Astruc Deulosal had married two sisters. Marriage to two sisters is permitted in Jewish law, but it is not permitted while the first sister is still alive ${ }^{12}$; nor for that matter has bigamy or polygamy been permitted to Jews in Christian Europe since the time of Rabbenu Gershom, in the eleventh century; it is to be assumed that Puigcerdá around the year 1300 followed his ruling.

But which of the sisters was his first wife? We cannot know the answer to this question, but, on the basis of what we know of the marital status of the three daughters of these two marriages, it is tempting to hazard a guess. Each of the three granddaughters had in the will of Gentill of 1306 received no more than 5 sous apiece. In the will of 1321, on the other hand, Sança-Adzero receives 100 sous, as against the five assigned to each of her sisters. Although the information given in the two documents is not wholly clear, both as to this and as to the marital status of these young women in general, this may indicate that Sança was at this stage unmarried, and if so, that her mother, Adzero (on the assumption that Sança of $1321=$ Adzero of 1306) was the second of the two sisters to have married Astruc Deulosal. If that is the case, and if in 1306 Sança-Adzero was already no longer an infant, then by 1321 , when she was sixteen years older still, her chances of marriage must have been declining fast.

12 Interestingly, the accusation that Judaism permits marriage to two sisters simultaneously had been made in the Iberian peninsula; in the middle of the eleventh century, Ibn Hazm, both in his Kitäb al-Fisal (a sort of comparative history of religions) and in his Radd'alä Ibn al-Naghrïla, an attack on Samuel ha-Nagid, the great Jewish vizier of Granada, had quoted the biblical example of Jacob and his marriage to Rachel and Leah. 


\section{RESUMEN}

Dos testamentos de judíos de Puigcerdá del siglo XIV nos permiten reconstruir las familias de los testadores. Los datos son tan semejantes entre sí que parece tratarse de una misma familia; sin embargo plantean dificultades ciertas divergencias, de cuya explicación nos ocupamos en este artículo. Además, desde el punto de vista estadístico parece muy probable la identidad de los dos grupos familiares: hay que tener en cuenta que en la Puigcerdá del momento no vivían más que unos centenares de familias, de las cuales sólo unas cincuenta eran judías.

\section{SUMMARY}

Two Jewish wills, fifteen years apart, in Puigcerdá in the early fourteenth century, enable us to reconstruct families. The reconstructions are so similar that they seem to be of a single family; but there are difficulties which make the identity less than perfect. Here, I attempt to reconcile the difficulties. The existence of only one family seems required by the overall statistics: Puigcerdá at this time had only a few hundred families altogether, and only ca. 50 Jewish families. 